
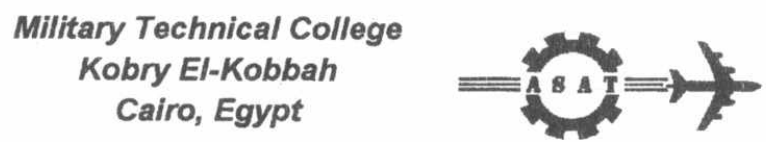

$10^{\text {th }}$ International Conference On Aerospace Sciences\& Aviation Technology

\title{
SELECTION AND PERFORMANCE OF HYBRID PROPELLANT PROPULSION SYSTEM
}

\author{
HOSAM* E. M., LUDVÍK**F.
}

\section{ABSTRACT:}

Hybrid propulsion systems have many advantages when compared to the conventional solid or liquid propellant propulsion systems. Trials leading to eliminate the LP disadvantages, based on theoretical as well as experimental research, lead to broader HPRM applications. In order to select the suitable propellant, it is better to investigate at first such combination of propellant components that have high initial density and secures chemical reactions with the highest reactivity.

This paper discusses some typical choices for fuel and oxidizer and advantages and disadvantages of each one. Comparing the magnitude of specific impulse, various fuel-oxidizer combinations and mass-mixing ratio, burning law exponent and optimum design of the solid fuel grain, help to obtain better HP advantages. Moreover, it is not beyond possibility that further dedicated research and development of the hybrid propellants will relieve some of the inefficiency problems and therefore boost the performance figures even higher. It is anticipated that hybrids could dominate the chemical propulsion field in that century.

\section{Nomenclature}

$\begin{array}{ll}A & \text { Constant of fuel regression rate } \\ A_{f} & \text { Surface area of the fuel grain }\left(\mathrm{m}^{2}\right) \\ D & \text { Combustion port diameter }(\mathrm{m}) \\ \mathrm{G}_{\mathrm{o}} & \text { Oxidizer mass flux }\left(\mathrm{kg} / \mathrm{m}^{2} . \mathrm{sec}\right) \\ \dot{\mathrm{m}}_{\mathrm{f}} & \text { Fuel mass flow rate }(\mathrm{kg} / \mathrm{sec}) \\ \dot{m}_{\circ} & \text { Oxidizer mass flow rate }(\mathrm{kg} / \mathrm{sec}) \\ \mathrm{n} & \text { Burning exponent } \\ \text { O/F } & \text { Oxidizer to fuel ratio } \\ \dot{\mathrm{r}} & \text { Regression rate }(\mathrm{m} / \mathrm{sec})\end{array}$

*Egyptian Armed Forces, MTC, Cairo-Egypt

** Professor, Dpt. of Rocketry, Military Academy in Brno, Czech Republic. 


\section{INTRODUCTION}

The primary characteristic of the hybrid rocket motor that distinguishes hybrids from solids and liquids is the non-explosively characteristic of the hybrid system. Another feature of hybrids is the relative ease with which they can be throttled. The rate of combustion of a hybrid is governed by the flow of oxidizer over the surface of the fuel, thus by throttling only the oxidizer the thrust can be modulated, that means that the termination of the oxidizer flow terminates also the HPM thrust

Since hybrids cannot explode, they are sufficiently safe regarding their manufacture and operation. This safety translates directly into reduced development and production costs. Furthermore, since the fuel in particular is non-hazardous, it can be cast simply and thus the need for expensive, remotely - controlled casting and curing facilities are eliminated. The system is insensitive to minor grain de-bonds and cracks, because the hybrid combustion process is driven by convective heat transfer from the hot gases flowing over the grain surface. In case of a crack, the flowrate of gases over the crack is very slow so the resulting combustion occures at a lower rate on the fuel grain surface. Thus, cracks are slowly eroded away with time, reducing the potential of a burn through to the motor case [1]. Therefore, the analysis of HP composition will be carried out and verified practically by firing tests.

\section{HYBRID PROPELLANT SELECTION}

In order to select the suitable propellant, it is better to investigate at first such combination of propellant components that has higher initial density and secures chemical reactions with the highest release of heat. The created combustion products have to be with the minimum possible molar mass to secure sufficiently high values of specific impulse. The possible states of fuel and oxidizer combinations are introduced in table 1, [2].

Table 1.

\begin{tabular}{|c|c|c|}
\hline $\begin{array}{c}\text { Series } \\
\text { number }\end{array}$ & Oxidizer & Fuel \\
\hline $\mathbf{1}$ & Gaseous & Gaseous \\
$\mathbf{2}$ & Gaseous & Liquid \\
3 & Gaseous & Solid \\
$\mathbf{4}$ & Liquid & Gaseous \\
$\mathbf{5}$ & Liquid & Liquid \\
6 & Liquid & Solid \\
$\mathbf{7}$ & Solid & Gaseous \\
$\mathbf{8}$ & Solid & Liquid \\
9 & Solid & Solid \\
\hline
\end{tabular}

From introduced combinations of fuels and oxidizers, combinations $1,4,7$ are useless due to gaseous fuel application. Series number $\underline{5}$ represents classical liquid rocket propellant. The main combinations are therefore $\underline{6,8}$ and partially $\underline{9}$. 
Usual types of the hybrid propellant are liquid oxidizer and solid fuel. Chemical agents that can be used as components of the rocket HP are substantially broad. Practically all fuels and oxidizers, forming the HP rocket at the present and future time are solid and liquid components. Possible used HP oxidizers are introduced in table 2, [3].

Table 2.

\begin{tabular}{|c|c|c|c|}
\hline Name & Chemical formula & State & $\begin{array}{c}\text { Density } \\
\left(\mathbf{K g} / \mathbf{m}^{3}\right)\end{array}$ \\
\hline $\begin{array}{c}\text { Liquid oxygen } \\
\text { Fluorine }\end{array}$ & $\mathrm{O}_{2}$ & Liquid & 1140 \\
Trifluorine & $\mathrm{F}_{2}$ & Liquid & 1510 \\
$\mathbf{9 8 \% \text { hydrogen peroxide }}$ & $98 \% \mathrm{H}_{2} \mathrm{O}_{2}, 2 \% \mathrm{H}_{2} \mathrm{O}$ & Liquid & 1830 \\
Liquid & 1437 \\
Nitrogen tetraoxide & $\mathrm{N}_{2} \mathrm{O}_{4}$ & Liquid & 1450 \\
Ammonium perchlorate & $\mathrm{NH}_{4} \mathrm{ClO}_{4}$ & Solid & 1950 \\
& $\mathrm{NO}_{2} \mathrm{ClO}_{4}$ & Solid & 2160 \\
Nitrogen perchlorate & $\mathrm{F}_{2} \mathrm{O}$ & Liquid & 1520 \\
Fluorine oxide & $\mathrm{C}\left(\mathrm{NO}_{2}\right)_{4}$ & Liquid & 1620 \\
Tetranitromethane & &
\end{tabular}

Possible used HP fuels are introduced in table 3.

Table 3.

\begin{tabular}{|c|c|c|c|}
\hline Name & $\begin{array}{l}\text { Chemical } \\
\text { formula }\end{array}$ & State & $\begin{array}{l}\text { Density } \\
\left(\mathrm{Kg} / \mathrm{m}^{3}\right)\end{array}$ \\
\hline Polyethylene & $\left(\mathrm{C}_{2} \mathrm{H}_{4}\right)_{\mathrm{n}}$ & Solid & 940 \\
\hline Synthetic rubber & $\mathrm{C}_{a} \mathrm{H}_{b} \mathrm{O}_{c} \mathrm{~N}_{d}$ & Solid & 1000 \\
\hline Lithium hydride & $\mathrm{LiH}$ & Solid & 800 \\
\hline Aluminum hydride & $\mathrm{AlH}_{3}$ & Solid & 1740 \\
\hline Aluminum lithium hydride & $\mathrm{AlLiH}_{4}$ & Solid & 920 \\
\hline Beryllium hydride & $\mathrm{BeH}_{2}$ & Solid & 1600 \\
\hline U-symm. Dimethylhydrazine & $\mathrm{H}_{2} \mathrm{~N}_{2}\left(\mathrm{CH}_{3}\right)_{2}$ & Liquid & 790 \\
\hline Hydrazine & $\mathrm{N}_{2} \mathrm{H}_{4}$ & Liquid & 1010 \\
\hline Pentadecane & $\mathrm{B}_{5} \mathrm{H}_{9}$ & Liquid & 630 \\
\hline Liquid hydrogen & $\mathrm{H}_{2}$ & Liquid & 71 \\
\hline
\end{tabular}


In accordance with the mentioned types of fuels and oxidizers, there exist the following groups of HP:

- $1^{\text {st }}$ group - solid fuel - liquid oxidizer;

- $2^{\text {nd }}$ group - solid oxidizer - liquid fuel;

- $3^{\text {rd }}$ group - solid oxidizer - solid fuel;

- $4^{\text {th }}$ group - three component hybrid propellants.

Presence of the $4^{\text {th }}$ group is due to the fact that three component HP reaches the highest specific impulse. Mostly used HP combinations are introduced in table 4, [4].

Table 4.

\begin{tabular}{|c|c|c|c|c|}
\hline $\begin{array}{l}\text { Code } \\
\text { of HP }\end{array}$ & Fuel & Oxidizer & $\begin{array}{l}\text { Mass mixing } \\
\text { ratio } K_{0}\end{array}$ & $\begin{array}{l}\text { Exploitation } \\
\text { feature of HP }\end{array}$ \\
\hline RT-1 & $\begin{array}{c}\text { Carbon Hydrogen } \\
\text { Polymer }\end{array}$ & $98 \% \mathrm{H}_{2} \mathrm{O}_{2}$ & $5.5-6.5$ & High boiling \\
\hline RT-2 & $\begin{array}{l}\text { Lithium Aluminum } \\
\text { Hydride }\end{array}$ & $98 \% \mathrm{H}_{2} \mathrm{O}_{2}$ & 1.08 & High boiling \\
\hline RT-3 & Aluminum Hydride & $98 \% \mathrm{H}_{2} \mathrm{O}_{2}$ & 1.02 & High boiling \\
\hline RT-4 & Beryllium Hydride & $98 \% \mathrm{H}_{2} \mathrm{O}_{2}$ & 1,57 & High boiling \\
\hline RT-5 & Beryllium Hydride & $\mathrm{N}_{2} \mathrm{O}_{4}$ & 1.67 & High boiling \\
\hline RT-6 & Lithium Hydride & $\mathrm{ClF}_{3}$ & 5.82 & High boiling \\
\hline RT-7 & $\begin{array}{c}\text { Carbon Hydrogen } \\
\text { Polymer }\end{array}$ & $\mathrm{O}_{2}$ & 2.4 & Low boiling \\
\hline RT-8 & Lithium Hydride & $\mathrm{F}_{2}$ & 4.30 & Low boiling \\
\hline RT-9 & Beryllium Hydride & $F_{2}$ & 2.11 & Low boiling \\
\hline RT-10 & $\begin{array}{l}\text { Non symmetric } \\
\text { dimethylhydrazine }\end{array}$ & $\mathrm{NO}_{2} \mathrm{ClO}_{4}$ & 2.4 & High boiling \\
\hline RT-11 & Hydrazine & $\mathrm{NO}_{2} \mathrm{ClO}_{4}$ & 1.12 & High boiling \\
\hline RT-12 & Pentadecane & $\mathrm{NO}_{2} \mathrm{ClO}_{4}$ & 3.40 & High boiling \\
\hline RT-13 & Aluminum Hydride & $\mathrm{NO}_{2} \mathrm{ClO}_{4}$ & 1.52 & High boiling \\
\hline RT-14 & Beryllium Hydride & $\mathrm{NO}_{2} \mathrm{ClO}_{4}$ & 2.20 & High boiling \\
\hline RT-15 & $80 \% \mathrm{BeH}_{2}+20 \% \mathrm{H}_{2}$ & $\mathrm{O}_{2}$ & 1.17 & High boiling \\
\hline RT-16 & $70 \% \mathrm{BeH}_{2}+30 \% \mathrm{H}_{2}$ & $\mathrm{O}_{2}$ & 0.88 & Low boiling \\
\hline
\end{tabular}

Thermodynamic characteristics (regardless possible losses) of above introduced HP compositions are determined for optimum ratio between components and chamber pressure four MPa are given in the table 5, [5]. 
Table 5.

\begin{tabular}{|c|c|c|c|c|c|}
\hline Group & $\begin{array}{c}\text { Cod of } \\
\text { HP }\end{array}$ & $\begin{array}{c}\text { Density } \\
\text { (Kgm }^{-3} \text { ) }\end{array}$ & $\begin{array}{c}\text { Burning } \\
\text { Temperature } \\
\text { (K) }\end{array}$ & $\begin{array}{c}\text { Specific impulse } \\
\text { (Nskg-1 }^{-1}\end{array}$ & $\begin{array}{c}\text { Specific volumetric } \\
\text { impulse } \\
\text { (kNsm }\end{array}$ \\
\hline I & RT-1 & 1360 & 3000 & 2570 & 3550 \\
& RT-2 & 1140 & 3068 & 2765 & 3235 \\
& RT-3 & 1580 & 3764 & 2882 & 4530 \\
& RT-4 & 1500 & 3096 & 3334 & 5030 \\
& RT-5 & 1510 & 3620 & 3235 & 4885 \\
& RT-6 & 1530 & 4190 & 2725 & 4170 \\
II & RT-7 & 1090 & 3600 & 2745 & 2990 \\
& RT-8 & 1290 & 4762 & 3406 & 4385 \\
& RT-9 & 1530 & 4830 & 3688 & 5650 \\
III & RT-10 & 1430 & 3466 & 2638 & 3775 \\
& RT-11 & 1450 & 3339 & 2745 & 3982 \\
& RT-12 & 1380 & 3950 & 3070 & 3903 \\
& RT-13 & 1800 & 3511 & 2696 & 4854 \\
& RT-14 & 1760 & 3275 & 3070 & 5395 \\
& RT-15 & 496 & 3507 & 3905 & 1932 \\
& RT-16 & 340 & 2821 & 4150 & 1412 \\
\hline
\end{tabular}

It is obvious from tables 4 and 5 that, the most acceptable is the $1^{\text {st }}$ group of HP (liquid oxidizer + solid fuel). Application of hydrogen peroxide as oxidizer is reasonable in two cases, i.e. propellant RT-1 has high value of components mixing ratio $\mathrm{K}_{\mathrm{opt}}=6 \div 7$. That means, $(1 / 6 \div 1 / 7)$ of the mass of propellant is located as solid grain in the combustion chamber, being stressed by high working pressure.

Majority of the propellant mass $(5 / 6 \div 6 / 7)$ is stored in loaded tank; therefore, the HP of the driving unit when RT-1 is applied can be realized with small specific mass. On the other hand, the hydrogen peroxide is mono component type of propellant. Such fact allows solving simply the task of gas generator operation needed for driving the gas turbine. Remaining HP compositions of the $1^{\text {st }}$ group belong to high boiling propellants and in comparison with others they have better energetic characteristics. The disadvantage of these HP is high cost. These types are therefore recommended for upper stages of multistage rockets or cosmic vehicles. Propellants RT- 8 and RT-9 have the smallest effectiveness in case of two component types. They have very high density with respect to the specific impulse.

The HP of the $2^{\text {nd }}$ group RT-10, RT-11and RT-12 are based on prospective solid oxidizer Nitrogen Perchlorate and differ by large amount of propellant stored in the combustion chamber and small amount in the propellant tank [4]. 
Usual ratios of components equal to $(2.5 \div 3.5)$. So, such disadvantage is partially compensated by higher density of the nitrogen perchlorate $\left(2600 \mathrm{Kgm}^{-3}\right)$. Regarding the chemical activity of $\mathrm{NO}_{2} \mathrm{CLO}_{4}$, the HP of the $2^{\text {nd }}$ group reacts reliably with small delay of propellant ignition when the contact of components is secured.

The $3^{\text {rd }}$ group of the HP such RT-13 and RT-14 are propellants with different applications; RT-13 considering that it will be mastered some ways of $\mathrm{AlH}_{3}$ synthesis and will be produced as solid blocks from them, having high density. HP produced on the base of Hydrazine (RT-14) has high price, as well as the toxicity and can be used for upper stages of multistage rockets.

The $4^{\text {th }}$ group of HP - three component types and their utilization presuppose that in the combustion chamber will be located solid fuel. They have the highest calculated values of specific impulses due to the high burning temperature of solid fuels with metallic agents in oxidizer and molar mass of combustion products (due to liquid hydrogen). According to the thermodynamic calculations, the utilization of RT-15 and $\mathrm{RT}-16$ for high working pressure and high expansion ratios of combustion products through the nozzle $\left(p_{c c} / p_{A}=2000 \div 4000\right)$ allows to raise the specific impulse until $10000\left(\mathrm{Ns} \mathrm{Kg}^{-1}\right)$ in comparison with the propellant $\left(\mathrm{LOX}+\mathrm{LH}_{2}\right)$.

More complicated construction of the HPM can be expected, due to necessary introduction of the $3^{\text {rd }}$ component, which has relatively low burning temperature. Unfortunately, there exist no notes about the practical applications. In addition, they are recommended for upper stages of multi stage rockets.

It is necessary to pay attention to the fact that all HPM contain sufficient amount of metals in their composition at which it is necessary to secure full burning of this metal. This can be described by the following:

HPM with propellant having the composition $\mathrm{BeH}_{2}+\mathrm{H}_{2} \mathrm{O}_{2}$ will have maximum specific impulse for such ratio of components, which secures full oxidation of Beryllium to $\mathrm{BeO}$ and creation of Hydrogen in free state as follows:

$$
2 \mathrm{BeH}_{2}+\mathrm{H}_{2} \mathrm{O}_{2} \rightarrow 2 \mathrm{BeO}+3 \mathrm{H}_{2}
$$

The part of Beryllium oxide in combustion products will be high $(\approx 0.892)$. So, for such high content of the condensed phase in the HPM nozzle, combustion products are accompanied by intensive enlargement of particles. This fact can lead to about $10 \%$ drop of specific impulse [4], [6].

\section{HYBRID PROPELLANT PERFORMANCE}

Regarding the comparison of the specific impulse magnitude for various possible fuel-oxidizer combinations, the specific impulse $\left(i_{\mathrm{sp}}\right)$ variation with the oxidizer/fuel ratio $(\mathrm{O} / \mathrm{F})$ is illustrated by Fig. 1. Hybrid propellant rockets unlike the case of solid and liquid rockets, the O/F ratio changes over the course of a normal burn for the case of a constant oxidizer flow rate.

This is because the fuel surface area increases as the fuel burns away [7]. For a fuel grain design with a single circular combustion port the surface area will increase with diameter

$$
\mathrm{A}_{\mathrm{F}}=\pi \mathrm{DL} \text {. }
$$


Thus for a constant fuel regression rate $\dot{r}$, the fuel flow rate will tend to increase with time as the diameter grows

$$
\dot{\mathrm{m}}_{\mathrm{F}}=\dot{\mathrm{r}}_{\mathrm{f}} \mathrm{A}_{\mathrm{f}} \text {. }
$$

However, this increase in flow rate is counteracted by a decrease in the fuel regression rate, which is a function of mass flow rate per unit cross-sectional area. A simple theoretical expression can be used in the evaluation of the regression rate, in a hybrid propellant motor, i.e.

$$
\dot{r}=A G_{0}{ }^{n} ; \quad G_{0}=\frac{\dot{m}_{0}}{\frac{\pi}{4} D^{2}},
$$

where the constant $\underline{A}$ varies with the fuel and oxidizer type, $\underline{n}$ is determined empirically (usually when using convenient regression analysis methods). The typical values of $\underline{n}$ fall between $\underline{0.5}$ and $\underline{0.8}$. As we can see from equation (1) and equation (3) the fue! flowrate actually varies inversely to the diameter, thus the O/F ratio in case of a single circular port will increase continually throughout the burning. This shift in $\mathrm{O} / \mathrm{F}$ ratio can be countered by throttling down during burning that has a good benefit of reducing the thrust as the mass is decreasing thus limiting the axial acceleration loads for the payload.

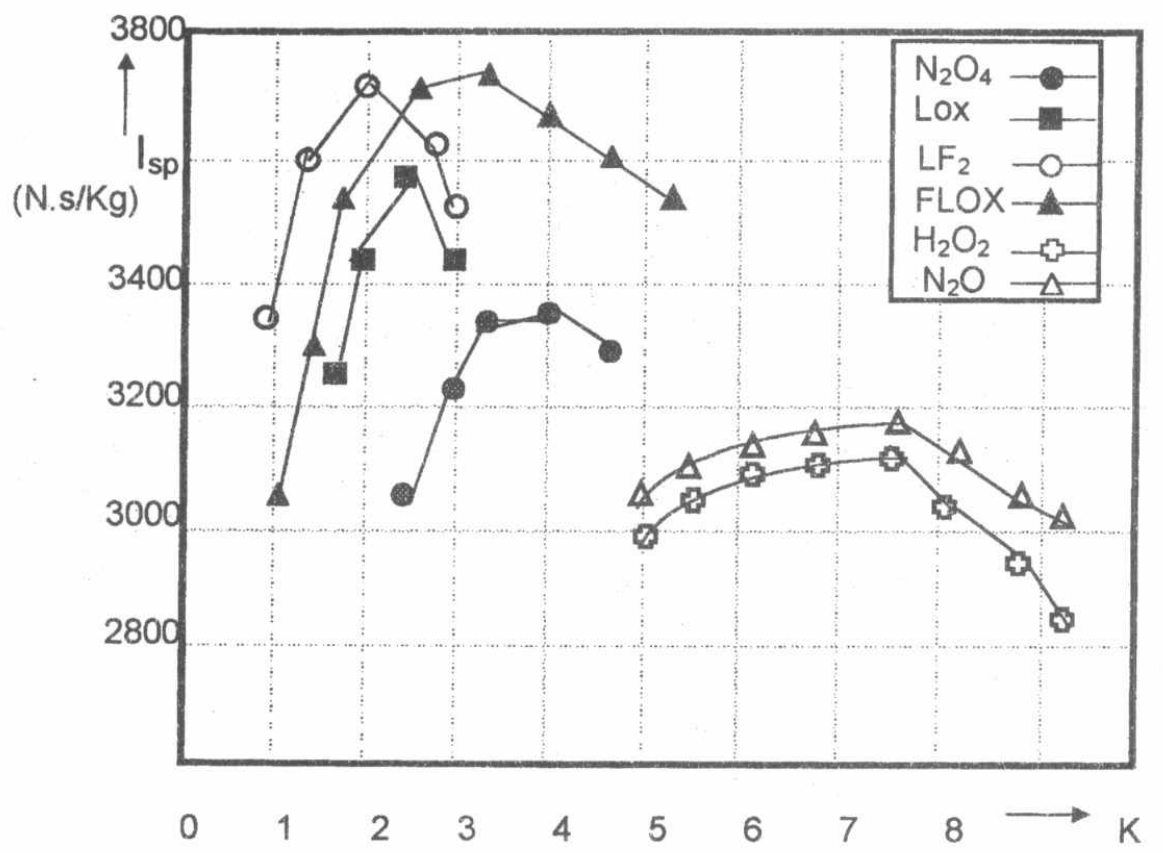

Fig. 1. Theoretical Performance of HTPB with Various Oxidizers 
Using equations 1,2 , and 3 can be shown that for a certain fixed diameter $D$ the O/F ratio shift as shown on Fig. 2 and Fig. 3 for a number of different values of $n$. The challenge to the hybrid motor designer is to select a fuel grain design so that the average O/F ratio is near optimum.

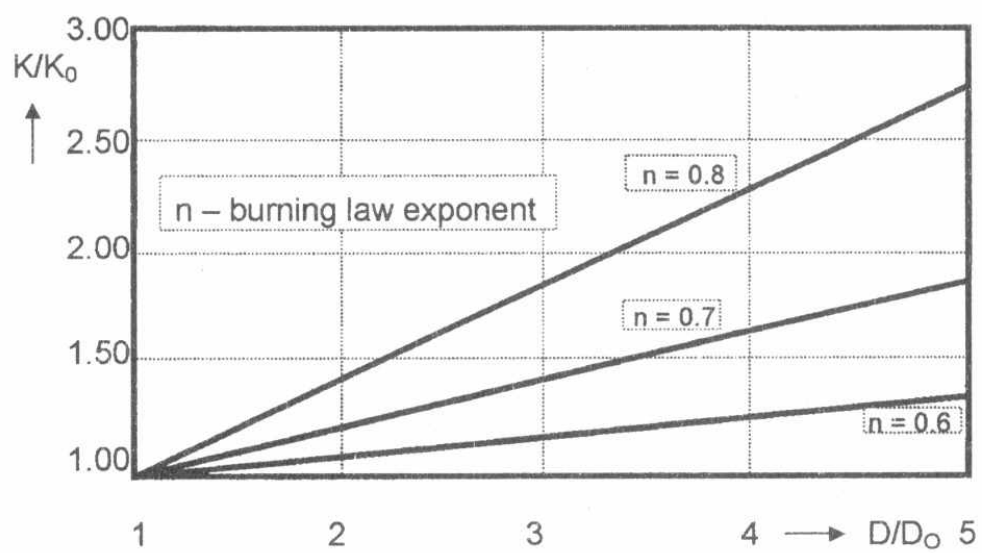

Fig. 2. Variation of $\mathrm{O} / \mathrm{F}$ ratio with fuel grain diameter

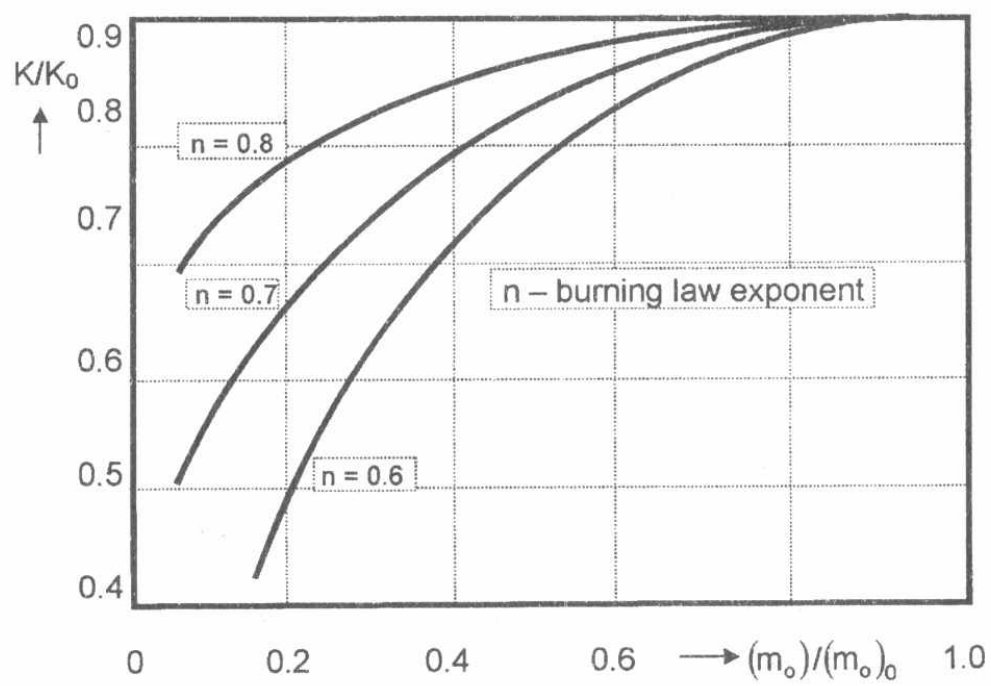

Fig. 3. Variation of $\mathrm{O} / \mathrm{F}$ ratio with oxidizer mass flow rate 


\section{CONCLUSION}

The paper collects important remarks about possible HP compositions, their properties, as well as advantages and disadvantages being necessary to assume for convenient HPM design as type of propulsion unit.

The proper selection of those propellants in order to meet the design goals of the propulsion system will vary assuming the mission requirements. Some of these features of different propellants have been discussed and need to be considered carefully in the design process. Having in mind the existing conditions, the verification of these theoretical approaches in the future solution will be related to HP composed from solid fuel (e.g. HTPB + additives) and gaseous oxidizer (gaseous oxygen). Such composition allows carrying out firing tests with convenient testing motor in order to contribute to the regression rate determination (as methodical approach to such solution).

Of course to construct a HP composition consisting of a liquid component and solid component from known types, the presupposed composition must fulfill the main requirements of the HPM and of course the required Iactical and Iechnical Requirements - (TTR) through the following:

$>$ High initial density of the HP;

$>$ Low burning temperature;

$>$ Suitable working pressure;

$>$ High specific impulse;

HP composition must be of known and simple method of ignition (or hypergolic)

$>$ Exhaust gases, as possible, not toxic, not smoky and with lower molecular mass.

In order to fulfill those requirements at first must be discuss the main problems facing the HP components, which are as a rule related to the rocket mission and construction.

\section{REFERENCES}

[1] KUO K. K.: "importance and Challenges of Hybrid Rocket Propulsion Beyond Year 2000", Propulsion Engineering Research Center, Department of Mechanical Engineering, Pennsylvania State University, USA, 1996.

[2] SUTTON, G.: "Rocket Propulsion Elements: An Introduction to the Engineering of Rockets", Sixth Edition, John Wiley \& Sons, 1992.

[3] LUDVÍK F. and HOSAM, M.: "Hybrid Propellant Rocket Motors", $4^{\text {th }}$ Conference on Weapon Systems, IDET 99, and Brno 4-6, May 1999.

[4] ALTMAN D.: "Hybrid Rocket Development History", AIAA Paper 91-2515, 27 ${ }^{\text {th }}$ AIAA Joint Propulsion Conference, Sacramento, CA, 24-26 June 1991.

[5] VOLKOV G. J. and SHISHKIN J. N.: "Rocket Motors with Combined Propellant", Moscow, 1973.

[6] HOSAM E. M. : "Hybrid Propellant Rocket Motors". Written Report for Rigorous Examination. Military Academy-Brno, 2000.

[7] PAUL N. ; ESTEY G. and R. WHITTINGHILL: "Hybrid Rocket Motor Propellant Selection Alternatives", American Rocket Company, Member of AIAA, 1992. 